\title{
GRAD KAO BEZBEDNOSNI SISTEM U PROŠLOSTI, SADAŠNJOSTI I BUDUĆNOSTI: GRANICE I URBANI DIZAJN
}

\author{
Miodrag Ralević ${ }^{1}$, Tatjana Mrđenović ${ }^{2}$ \\ UDK=711.4:351.778.5 \\ https://doi.org/10.18485/fb_ubur.2018.1.ch20 \\ ${ }^{1}$ Arhitektonski fakultet, Univerzitet u Beogradu, \\ tenibak.elar@yahoo.com \\ ${ }^{2}$ Arhitektonski fakultet, Univerzitet u Beogradu, \\ tmrdjenovic@gmail.com,tmrdjenovic@arh.bg.ac.rs
}

\section{Sažetak}

Osnovna svrha i sveopšti cilj nastajanja, formiranja i postojanja gradova nedvosmisleno je ostvarivanje bezbednosti za žitelje grada na svim nivoima. Grad je u suštini, sâm za sebe, kroz svoje trajanje, u stvari prevashodno bezbednosni sistem. Bez postojanja bezbednosne dimenzije grad bi gubio svrhu svog postojanja i značaja, kao i privlačne snage. Bezbednost grada započinjala je od traganja i izbora nepristupačne i teško dostupne lokacije za smeštaj bilo kojeg urbanog sistema, preko izgradnje zaštitne ograde - izgradnjom tvrđenja i odbrambenog zida oko tvrđavskog grada - pa preko strogo kontrolisanog ulaska u grad i strogo kontrolisanog ulaska u grad, uslovljenog davanjem statusa „građanina“ pojedincima ili grupama, familijama, određenim slojevima.

Tek od trenutka kada grad počinje širenje svojih zidina počinje da se uvodi apsolutnost postizanja bezbednosti ovog zatvorenog bezbednosnog sistema. Od tada počinju da se ,uspostavljaju“ različite vrste modela bezbednosnih sistema, odnosno formiranje razuđenih modela bezbednosnih gradova koji su se odlikovali, međusobno prepoznavali po konceptu ostvarenja funkcionalne bezbednosti. $U$ tom smislu cilj ovog rada je prepoznavanje relacije između uticaja bezbednosnog sistema na formiranje konceptualnih razvojnih modela gradova koji su nastali i menjali se kroz vreme kao, posledično gledano, pokušaj traganja za odgovorom kakve bezbednosne mere i sistemi (metode, načini i modeli bezbednosti) presudno utiču na komponovanje i razvoj gradova budućnosti. U tom kontekstu, možemo preliminarno identifikovati sledeću skalu modela „,bezbedn[osn]ih gradova“, koji su u sebe ugrađivali posebne bezbednosne sisteme, odnosno čiji je koncept pravila proizlazio zapravo iz tih modela. U ovom trenutku možemo uočiti sledeće modele bezbednih gradova:

- $\quad$ strogo kontrolisani gradovi,

- starosno segregirajući gradovi,

- institucionalno-bezbednosno kontrolisani gradovi,

- otvoreni gradovi,

- kulturološko-edukativni gradovi,

- tržišno-razvojni koncept bezbed[nos]nih gradova,

- upravljačko-razvojni bezbed[nos]ni gradovi,

- produkciono-kreativni koncept grada,

- pametni gradovi,

- $\quad$ informatički zasnovani bezbed[nos]ni gradovi. 
Grad kao kulturni artefakt ima primarnu ulogu u obezbeđivanju sigurnosti za svoje građane i za resurse koje baštini. Budući takav, on čuva kulturu i tradiciju kao proizvod naše civilizacije, zajedno sa resursima koji su ključni za preživljavanje i napredak ljudi. Morfološki obrasci urbanog dizajna govore nam umnogome o svojim konceptima urbane bezbednosti: od utvrđenja do umrežavanja; otvaraju pitanja o tome kakav nam je urbani dizajn danas potreban kako bi se različiti kulturni obrasci integrisali u svakodnevni život grada, obezbeđujući „samokorekcije“ u njegovom ponašanju u cilju rezilistentnosti na bilo kakvu vrstu brutalnih činova u urbanim prostorima, kao obezbeđenja kvaliteta mesta na svim njegovim prostornim nivoima od makro- do mikrourbanog dizajna. Rad razmatra urbanu bezbednost sa aspekta vrsta granica u urbanim paradigmama, a naročito u urbanom dizajnu pod pretpostavkom da integralni/kooperativni urbani dizajn može obezbediti adekvatan nivo otvorenosti kako u cilju povećanja rezilistentnosti na bilo kakav oblik nasilja. Stoga će se istraživanje osloniti na koncept rezilijentnosti, sistemsko urbanističko planiranje, teoriju socijalnog kapitala kao produktivnu gradsku snagu koja povezuje urbanističku formu i morfologiju, uzimajući u obzir različite teorije urbanog dizajna: prostornu sintaksu, sliku grada, arhitekturu i disjunkciju, kao i kooperativan urbani dizajn. Cilj rada je da rasvetli odnos između vrste društvenog kapitala, tipa granica koje produkuje i urbanog dizajna, što će rezultovati klasifikacijom relacija između teorije urbanističkog dizajna, tipa socijalne rezilistentnosti, vrsta granica granica i nivoa urbane bezbednosti.

Ključne reči: urbani dizajn, bezbednost, rezilijentnost, socijalna rezilistentnost

\section{Uvod}

Globalni grad odražava i tamne i svetle strane globalizacije u svim njegovim aspektima: socio-ekonomskim, kulturnim, institucionalnim, prirodnim, informatičko-tehnološkim. Proces globalizacije postavlja pred nerazvijene i gradove u razvoju dilemu: treba li otvoriti kapije za umrežavanje ili izgraditi jača utvrđenja da bi preživeli kulturnu i sve druge vrste devastacije koje primarni gradovi-kulture donose kroz globalne mreže. Prema Kastelsu gradovi koji nisu u globalnoj mreži žive u „lokalnom kavezu“, te kao takvi nemaju nikakve koristi koje im donosi kulturna ili bilo kakva interakcija (Castells, 2000).

Izgradnja granica ili otvorenost ka drugosti pružaju nam šansu ili rizik za antropološki/morfološki razvoj kada treba promisliti o našim životnim obrascima kako bismo preživeli šokove i stresove koji potiču iz spoljašnje mreže. Otpornost na stres znači usvajanje i promenu u novim uslovima, u vremenskom rasponu takvom da naša inteligencija može uspostaviti nove karakteristike, gradske entitete i reorganizaciju, time postajući evolutivna analogno ekološkim sistemima. To znači kako bi grad trebalo da preispita sopstvene obrasce koji će osigurati da glavni kulturni i društveno-ekonomski entitet preživi i preuzme novu poziciju u revitalizovanju grada. 
Tako je npr. šok industrijalizacije rezultovao uništavanjem gradskih fortifikacija, dok je bezbednost dostignuta kroz prostorno zoniranje i infrastrukturu. Takođe, Berlinski zid oličava dualni odnos između njegovog značenja i uloge, jer je predstavljao svojevrstan čin krivičnog i nasilnog delovanja nad društvenim i kulturnim kapitalom. Ovakvi procesi prisutni su od prvog urbanog naselja, gradskog entiteta, a akumulacija kapitala uzrokovala je evoluciju od (pre)urbanih načina življenja. Tema koju želimo da elaboriramo odnosi se na pitanje granica u urbanom dizajnu, a naročito u komunikacionoj urbanoj paradigmi.

Prema agendi UN-Habitata: „Bezbedniji gradovi zasnovani su na instrumentima lokalne samouprave koji promovišu dobro upravljanje, adekvatno urbanističko planiranje i upravljanje kao sredstva za razrešavanje kriminala, nasilja, sukoba i nesigurnosti u gradovima i ljudskim naseljima. To je multisektorski i multidisciplinarni pristup koji se primenjuje na lokalnom nivou zasnovanom na zajednici, fokusiranom na uključivanje svih interesnih strana i saradnju kako bi se ostvarila bezbednost i sigurnost za sve.“ (UN-Habitat, 2016)

Prvo poglavlje će razmatrati grad kao sigurnosni sistem u pogledu granica koje pruža i tipa socijalne strukture, dok će drugo razmatrati dizajn grada kroz predstavljanje glavnih teorija i njihovu društvenu rezilistentnost ${ }^{1} \mathrm{u}$ obezbeđivanju urbane bezbednosti.

\section{Pitanje granica i grada}

Grad kao sigurnosni sistem oduvek je bio entitet za očuvanje kulturnih resursa koji su fundamentalni za bilo koju vrstu preživljavanja. Glavne kulturne revolucije: poljoprivredna, industrijska, informatička (Castells, 2000). uticale su na ideju grada, posebno u pogledu njegovog oblika, morfologije i glavne uloge postojanja. Potreba za pronalaženjem skloništa od prirodnih, ekonomskih, kulturnih, verskih hazarda i katastrofa nametnula je specifične granice koje su gradovi razvijali tokom istorije kako bi mogli da opstanu u odnosu na nove izazove koji dolaze iz spoljnog sveta. Koncept granice koja se stavlja u fizički ili filozofski prostor uvek ima istu ulogu da sačuva određene vrednosti. U globalnom svetu otvaraju se nova pitanja: da li je granica premeštena da bismo bili sigurni na način da se naše vrednosti obelodanjuju kao održive? Šta znači imati rezilistentne granice koje omogućavaju sigurnost gradskog sistema?

Koncept rezilijentosti je relativno nov; međutim, on je tesno povezan sa pitanjem granica i gradskog razvoja. Rezilijentnost znači uočavanje spoljne pretnje (ekološke, ekonomske, kulturne, socijalne, verske) i iznalaženje tipova granica koje su adekvatne pitanjima razvoja i kolapsa. Drugim rečima, ako izgradimo snažne

1 Rezilistentnost (engl. resilience) etimološki podrazumeva ujedno otpornost i razvojnost (rezilirati - odustati od nečega; resistance - pružati otpor nečemu), podrazumevajući kapacitet za oporavak ili prilagođavanje stresu ili promeni zadržavajući primarne identitete i karakteristike (www.meriamwebster.com); upućujući time i na konsistentnost/istrajnost. 
granice prema spoljašnjem svetu, nismo elastični za promene, tj. tokom godina naš svet postaje sve više plastičan, dok ćemo u susretu sa novom pretnjim kolabirati bez ikakvih mogućnosti za ponovno uspostavljanje autentičnog identiteta. Rezilistentnost podrazumeva adaptaciju, usvajanje novih obrazaca i prilagođavanje novim uslovima, koji se baziraju na ključnim entitetima gradograđenja, fraktalima kulturnih, ekoloških, društvenih, institucionalnih, morfoloških sistema (Holling, 2001). (Videti Shemu 1.)

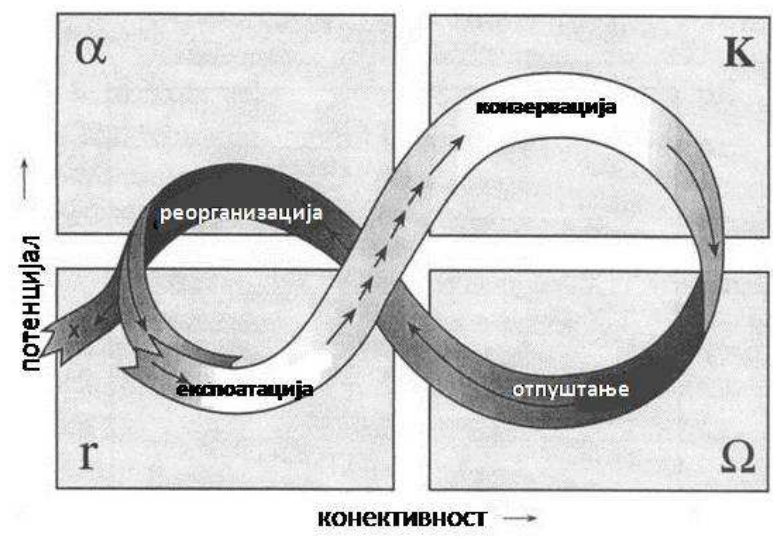

početno stanje

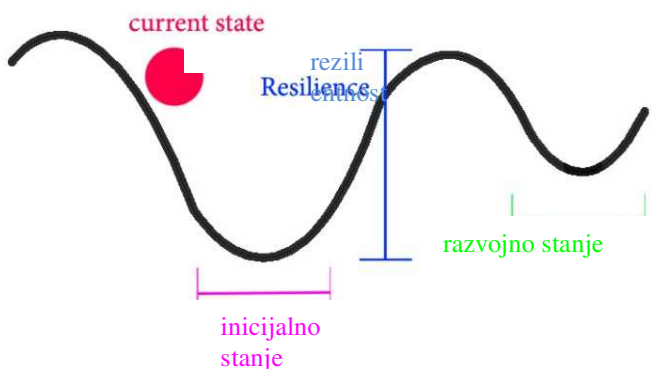

Shema 1. Stilizovana predstavljenost četiri funkcije ekosistema $(\mathrm{r}, \mathrm{K}, \alpha, \Omega)$ i tok događaja među njima (Holling, 2001: 394), https://www.e-education.psu.edu/geog30/sites/www.eeducation.psu.edu.geog30/files/M02_resilience\%20pic.jpg

Shema 1 predstavlja rezilijentni sistem koji se tokom vremena iterativno razvija u nove, pametnije entitete, putujući kroz petlje razvoja samoreorganizacije ne bi li sistem odgovorio na bilo kakve novine koje dolaze iz spoljnog okruženja i uspostavio proces širenja kognicije o samospoznaji i spoznaji drugih subjekata. 
Pitanje postojanja granica je i dalje izraženo, posebno njihova uloga u savremenom gradu, a koje zapravo u informatičkim i komunikacionim paradigmama ne postoje. Možemo reći je grad kao sistem ograničen našom inteligencijom i znanjem za iskorišćavanje prilika i prevazilaženje pretnji. U skladu sa tim, urbana bezbednost je snažno povezana sa našim znanjem, posebno sa društvenim znanjem i njegovim razvojnim potencijalom, a što će biti dodatno elaborirano. U ovom trenutku možemo reći da rezilistentnost uključuje i inteligenciju bilo koje vrste - ili, drugim rečima, razvijanje rezilistentnih granica sistema (Slika 1).
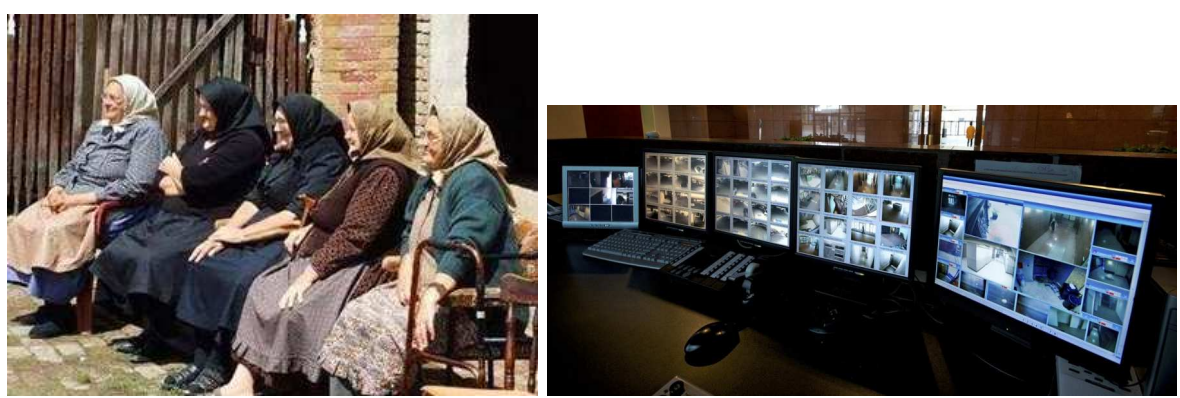

Slika 1. Društveni i tehnološki sistemi - sistemi granične kontrole

Rezilistentnost susrećemo i u sistemsko-ekološkim teorijama i više je povezana sa Faludijevim multiplanerskim agencijama (Faludi, 1984) i sistematskim pristupom upravljanja gradovima nego što se to čini na prvi pogled. Imajući u vidu činjenicu da glavna kritika instrumentalnosti njegove teorije ne stoji, jer se Faludi oslonio na pretpostavku da postoji konsenzus o glavnim vrednostima i društvenim pravcima, međusobna veza sa Hilinim kolaborativnim i inkrementalnim planiranjem i razvojem grada (Healey, 1997) prilično je tesna, čineći osnov za integrativni i rezilistentni razvoj grada. Jedina moguća kritika Faludijeve teorije planiranja jeste odsustvo koncepta koja će elaborirati način izgradnje konsenzusa. Ovo je tačka u kojoj je teorija saradnje odnosno kolaborativnosti kompatibilna sa sistemskim pristupom, stvarajući integrativni i rezilistentni sistem za bilo koju vrstu spoljašnjeg stresa kroz uspostavljanje polupermeabilnih granica.

Globalne gradove, kao što je ranije pomenuto, uglavnom definiše komunikaciona teorija i teorija sukoba, gde komunikativni grad predstavlja obeležje u kojem granice treba da se redefinišu u Habermasov prostor za komunikacijsku akciju. Ako uzmemo u obzir Habermasovu teoriju (Habermas, 1984), problem granica je više definisan preprekama u komunikaciji koje proizlaze iz različitih odnosa moći nego sa fizičkih granica, koje su danas u globalnom svetu prevaziđene. Danas u razvoju grada govorimo više o „osnaživanju“ nego o ,praktikovanju instumentalne moći“ (Dovey, 1999), gde mi, arhitekti i urbanisti, imamo zadatak čovečanstva da osnažimo marginalne grupe i oslobodimo granice gradskog sistema. U tom pogledu biti bezbedan znači biti komunikativan, stvarajući prostore za komunikativnu akciju.

Ove vrste prostora kreiraju intelektualaci, umetnici, zanatlije, obeležavajući ih kreativnošću kao instrumentom za prevazilaženje konflikata i međusobnih 
barijera u komunikaciji. Takvi prostori omogućavaju komunikativni tok i većinom se realizuju u javnim, performabilnim prostorima, poput ulica, galerija, muzeja. Čumijev (Tschumi, 1994) akt nasilja sada je akt bezbednosti koji ukazuje na greške u sadašnjem sistemu, posebno u sistemu socijalnog kapitala.

Stoga, da bi bio rezilistentan, grad mora da ponovo definiše i reorganizuje strukturu društvenog kapitala kako bi se obezbedile procedure i protokoli komunikacije koje omogućavaju rezilistentne društvene granice omogućavajući fleksibilnost na bilo kakav unutrašnji ili spoljni stres koji se odnosi na bezbednosna pitanja. Već je ranije pomenuto: „Bezbedniji gradovi zasnovani su na instrumentima lokalne samouprave koji promovišu dobro upravljanje, odgovarajuće urbanističko planiranje i upravljanje kao sredstva za razrešavanje kriminala, nasilja, sukoba i nesigurnosti u gradovima i ljudskim naseljima. To je multisektorski i multidisciplinarni pristup koji se primenjuje na lokalnom nivou zasnovan na zajednici, fokusiran na uključivanje interesnih strana i saradnju kako bi se ostvarila bezbednost i sigurnost za sve." (UN-Habitat, 2016)

\section{Urbani dizajn, socijalna rezilistentnost i urbana bezbednost}

Ključni faktor u urbanoj bezbednosti u odnosu na globalne gradove i komunikacijsku paradigmu sastoji se u povezivanju. Ako uzmemo u obzir jednu od glavnih teorija urbanog dizajna kao što je Hilerova Prostorna sintaksa (Hillier, 2004), Linčova Slika grada (Linč, 1974) ili Madanipurov Urbani dizajn kao proces (Madanipour, 1996), možemo reći da je pitanje prostorno-društvenog povezivanja od ključnog značaja u cilju kreiranja bezbednih prostora. Ovo je naročito elaborirano u Hilijerovoj teoriji grada, gde se on zalaže za matematičko programiranje društvenih prostora kroz teoriju grafova koji dokazuju da su mesta sa više veza sigurnija i socijabilnija (Shema 2).

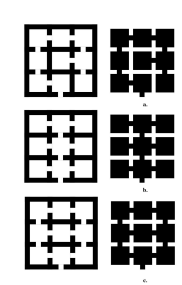

Shema 2. Prostorna sintaksa i društvene mreže (Hillier, 2004) 
Poredeći prostornu sintaksu i kooperativan pristup urbanom dizajnu, nalazimo vezu u ukidanju barijera i redefinisanju odnosa moći kako bi se stvorio prostor za komunikaciju koji rezultuje komunikacijskim konsenzusom o tome koju vrstu mesta želimo da bismo se osećali bezbednim i srećnim. Komunikativna mesta su glavni stub u Madanipurovoj teoriji procesnog urbanog dizajna, (Madanipour, 1996) dajući novu dimenziju Hilerovom prostoru - sintakse (Hillier, 2004), a posebno u smislu značenja prostora i njegovog stvaranja i re-kreiranja (Slike 2, 3). Stvaranje mesta bezbednosti, osećanja sreće i blagostanja jedna je od glavnih uloga arhitekata i urbanih dizajnera. Sa druge strane, Linč se zalaže za kognitivno mapiranje u dizajnu grada gde su granice ključne za stvaranje identiteta mesta i osećaj pripadnosti prostoru (Linč, 1974), što pribavlja veću sigurnost i bezbednost (Slika 4). Štaviše, Čumi se zalaže za svaku vrstu ludosti i istupa u prostoru koja može reorganizovati društvenu strukturu (Tschumi, 1994) (Slika 5).

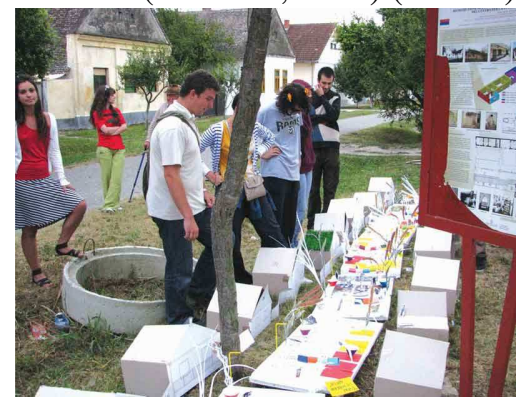

Slika 2. Urbani dizajn kao proces komunikativne akcije (Mrđenović, 2010)

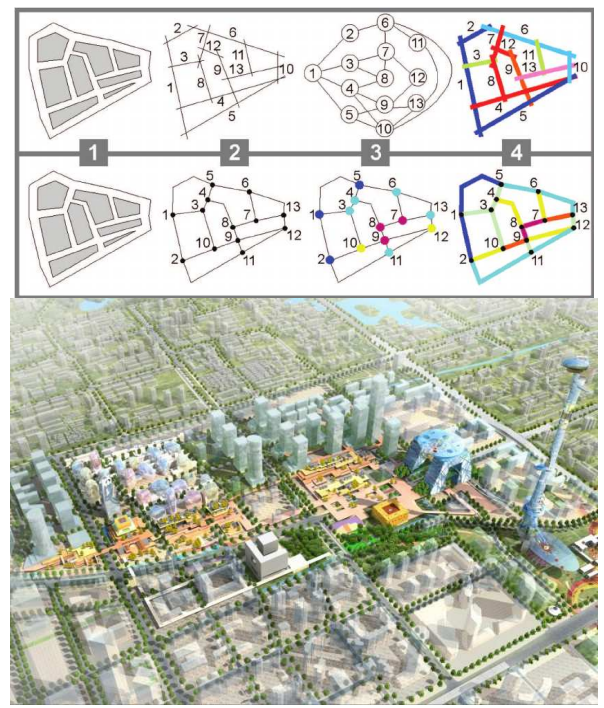

Slika 3. Prostorna sintaksa za bolju povezanost, društvenu bezbednost i socijabilnost. Nivo bezbednosti je direktno povezan sa nivoom otvorenosti mesta. 

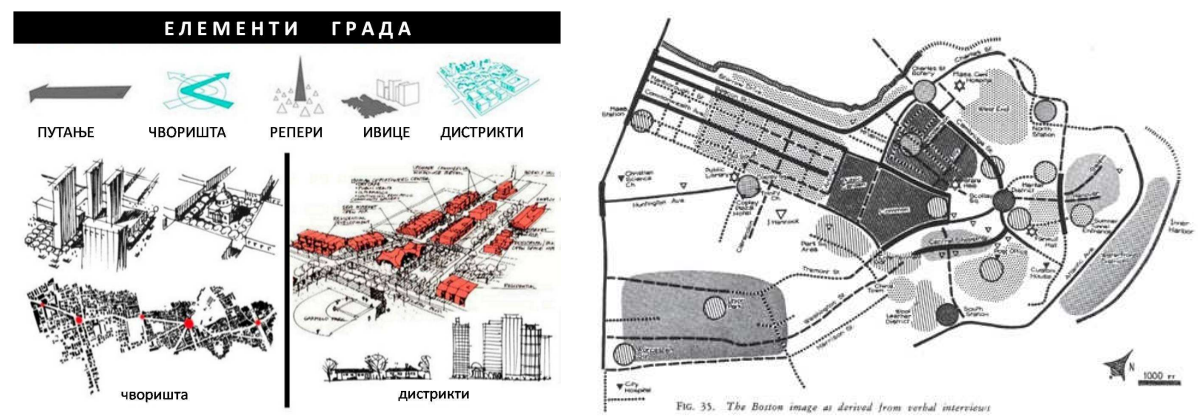

Slika 4. Linčovi elementi gradskog prostora

(Linč, 1974)
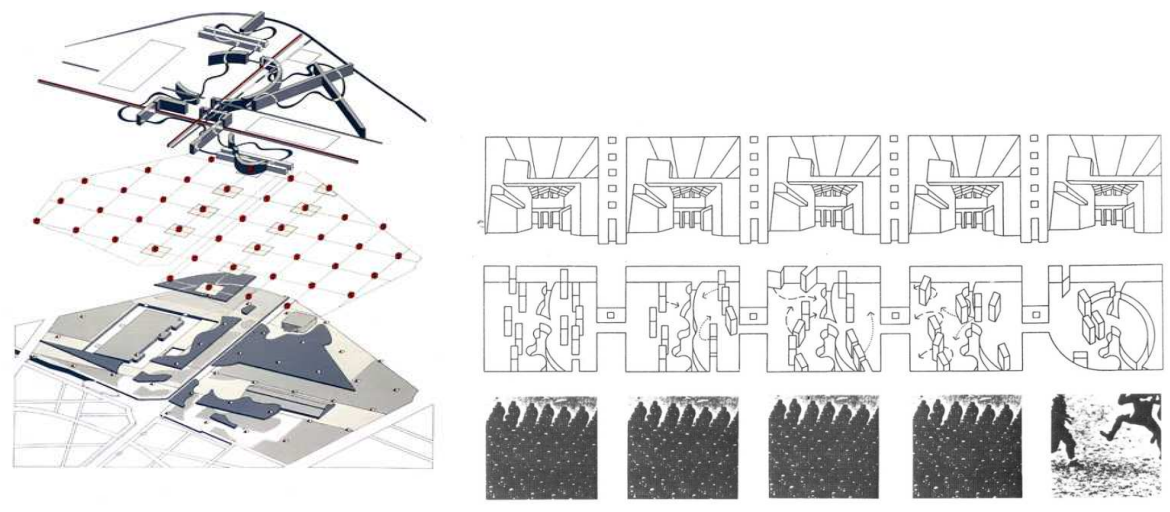

Slika 5. Arhitektura i disjunkcija.

Prestup u prostoru za društvenu reorganizaciju i ponovnu stabilizaciju (Tschumi, 1994)

Uspostavljanje veze između teorije socijalnog kapitala i socijalne rezilistentnosti, kao ključnim faktorima urbane bezbednosti, sa teorijama urbanog dizajna omogućavaju njihovu valorizaciju prema vrsti mreže socijalnog kapitala koje pruža određena teorija urbanog dizajna. Prema teoriji socijalnog kapitala postoje dve glavne kategorije u kojima je socijalni kapital klasifikovan na osnovu kriterijuma nivoa otvorenosti i vrste eksternalija koje proizvodi. Dakle, prva kategorija, poznata kao zatvoreni društveni kapital, reprodukuje norme i ponašanje u zajednici, potiskujući bilo koju vrstu individualnosti, inovativnosti i razvoja na nadražaje koji dolaze iz spoljnog sistema. Druga kategorija, poznata kao otvoreni društveni kapital, bazirana je na otvorenosti prema novini u ponašanju dajući priliku pojedincima da izraze svoj identitet, kao i da se ponovo organizuju kao reakcija na šokove, hazarde i izazove koji nastupaju spolja. 
Stoga možemo reći da je socijalna rezilistentnost direktno povezana sa vrstom društvenih mreža koje se proizvode u zajednici. Otvoreni društveni kapital, poznat i kao razvojni (Woolcock, 1999), zasnovan je na razvoju društvene strukture prema spoljašnjim stresovima (negativnim ili pozitivnim). Kao takav, ima tri razvojne faze: formiranje zajednice, povezivanje i stvaranje partnerstava. Formiranje društvene grupe ili lokalne zajednice, koja se povezuje se spoljšnjim mrežama i kreira partnerstva sa drugim zajednicama, rezultuje u stvaranjem novih konsenzusnih vrednosti, kao i kreiranjem supraorganizacija koje mogu odgovoriti na bilo kakve šokove spolja i biti rezilistentnije na globalne izazove (videti Sliku 1).

U skladu sa tim, socijalna rezilistentnost označava otvorene društvene sisteme koji su tradicionalno zasnovani i globalno povezani, tako da se mogu usvojiti, reorganizovati i razvijati u odnosu na bilo kakvo pitanje bezbednosti koje je u okviru ovog istraživanja (kulturno, društveno-ekonomsko, kriminalno itd.). Možemo reći da socijalnu rezilistentnost karakterišu: konektivnost, sistemski razvoj, brisanje granica među razvojnim sektorima - jedan od glavnih stubova modernog upravljanja agende UN-Habitata za postizanje urbane bezbednosti, komunikativna akcija.

Socijalna rezilistentnost obezbeđuje viši nivo urbane bezbednosti zajedno sa razvojnim društvenim kapitalom, bledim granicama moderne uprave. Prema agendi UN-Habitat-a, moderna uprava je od ključnog značaja za urbanu bezbednost, što znači brisanje granica između aktera koji su kreatori urbanog dizajna, čineći ih aktivnim učesnicima u svakodnevnom životu, međusobno povezanih $\mathrm{i}$ društveno obezbeđenih na različitim nivoima sistema upravljanja. To znači razvoj kako Faludijevog, tako i Hilinog gradskog sistema, ali i njihovo međusobno umrežavanje. U skladu sa prezentovanim, vrsta teorije urbanog dizajna nalazi se u direktnoj vezi sa nivoom socijalne rezilistentnosti i urbane bezbednosti.

\section{Zaključci: vrste granica u urbanom dizajnu za društvenu rezilistentnost}

Rad je razmatrao četiri različite teorije urbanog dizajna, uspostavljajući veze sa vrstama granica različitih vrsta društvenog kapitala. Prva elaborirana, poznatija kao kolaborativni/kooperativni urbani dizajn (Madanipour, 1996), zasniva se na sistemskom i saradničkom delovanju, naglašavajući participativni proces urbanog dizajna i nivoa osnaživanja zajednice putem komunikativnog konsenzusa u kojem treba prevladati granice/prepreke u komunikaciji kako bi se stvorili zajednički prostori i osećaj pripadnosti, kao jedan od glavnih principa sigurnosti i bezbednosti.

Druga sagledana koncepcija, poznata pod imenom Slika grada (Linč, 1974), počiva na odražavanju kognitivnog mapiranja gradskih korisnika u prostor, potcrtavajući granice i ivice kao jedan od glavnih principa stvaranja mesta koji obezbeđuje normativni, zatvoreni društveni kapital sa definisanim granicama samoproizvodnje i društvene reprodukcije i koji kao takav ima nizak stepen društvene rezilistentnosti na spolja izazvane stresove, pa stoga i nizak stepen urbane bezbednosti bilo koje vrste, naročito kulturne, kada šokovi različitog kulturnog korišćenja prostora mogu redefinisati upotrebu prostora, čime se neformalne aktivnosti odvija- 
ju u nekompatibilnim prostorima, otvarajući rizik za viši nivo kriminala i negativne eksternalije marginalnih socio-kulturnih grupa, koji izazivaju bezbednosne hazarde.

Treća elaborirana zamisao, poznata kao Prostorna sintaksa (Hillier, 2004), ukazuje na značaj bliže povezanosti mesta za viši nivo urbane sigurnosti. Hiler dokazuje da mesta sa jednom vezom prema drugom mestu imaju veći potencijal za bilo koju vrstu kriminalne aktivnosti, jer nisu nadgledana na različitim društvenim nivoima, kao ni od strane različitih društvenih grupa, tj. korisnika prostora. Hiler se zalaže za granice koje imaju kontrolisane kapije, kakve omogućavaju društvenu interakciju, umrežavanje i drugi nivo razvojnog društvenog kapitala: povezivanje.

Četvrta elaborirana vizija, poznata kao Arhitektonska disjunkcija (Tschumi, 1994), pruža sve elemente za razvojni socijalni kapital, stvarajući mesta za društveni prestup (folie) i stabilizaciju, prevazilazeći bilo kakve granice i norme koje inhibiraju dualitet, pluralitet i društveni čin. Stoga, Čumi otvara prostor za razvojni društveni kapital i socijalnu otpornost bilo koje vrste, obezbeđujući prostore za spoljne i unutrašnje šokove, kao i mesta za stabilizaciju, time čineći dinamične, otporne urbane prostore koji su karakteristični za samoregulaciju (videti Shemu 1).

Tabela 1. Klasifikacija teorija/koncepata urbanog dizajna, društvene rezilistentnosti, vrste granica i urbane bezbednosti

\begin{tabular}{|c|c|c|c|}
\hline Teorija urbanog dizajna & \begin{tabular}{|l|} 
Tip društvenog \\
kapitala/povezanosti
\end{tabular} & Tip granica & \begin{tabular}{|l|} 
Nivo urbane \\
bezbednosti
\end{tabular} \\
\hline $\begin{array}{l}\text { KOLABORATIVNI/ } \\
\text { KOOPERATIVNI } \\
\text { URBANI DIZAJN }\end{array}$ & $\begin{array}{l}\text { Obezbeđuje razvojni } \\
\text { društveni kapital koji } \\
\text { omogućava društvenu } \\
\text { rezilistentnost putem } \\
\text { Habermasove } \\
\text { komunikativne akcije }\end{array}$ & $\begin{array}{l}\text { Zamagljene. Rušenje } \\
\text { granica/barijera u ko- } \\
\text { munikaciji za osna- } \\
\text { živanje marginalnih } \\
\text { grupa u cilju njihovog } \\
\text { uključenja u socio- } \\
\text {-prostorne mreže. }\end{array}$ & $\begin{array}{l}\text { Urbana bezbednost je } \\
\text { usaglašena putem } \\
\text { komunikativnog čina i } \\
\text { društvenog sistema } \\
\text { nadgledanja i razvoja } \\
\text { uprave. }\end{array}$ \\
\hline SLIKA GRADA & $\begin{array}{l}\text { Omogućava stabiliza- } \\
\text { ciju normativno, } \\
\text { relativno zatvorenog } \\
\text { društvenog kapitala } \\
\text { samoreprodukcije sa } \\
\text { niskim nivoom dru- } \\
\text { štvene rezilistentnosti. }\end{array}$ & $\begin{array}{l}\text { Definisane u } \\
\text { gradskom prostoru, } \\
\text { putem ivica i } \\
\text { distrikata. }\end{array}$ & $\begin{array}{l}\text { Urbana bezbednost se } \\
\text { delegira institucijama. }\end{array}$ \\
\hline PROSTORNA SINTAKSA & $\begin{array}{l}\text { Povezivanje. Od } \\
\text { normativnog do } \\
\text { razvojnog društvenog } \\
\text { kapitala uzrokovanog } \\
\text { nivoom povezanosti. } \\
\end{array}$ & $\begin{array}{l}\text { Granice sa otvorenim } \\
\text { kapijama. } \\
\text { Povezivanje je glavno } \\
\text { pitanje socijalnog } \\
\text { kapitala } \\
\end{array}$ & $\begin{array}{l}\text { Nivo urbane } \\
\text { bezbednosti je direktno } \\
\text { povezan sa nivoom } \\
\text { konektivnosti. }\end{array}$ \\
\hline \begin{tabular}{|l|} 
ARHITEKTURA I \\
DISJUNCIJA
\end{tabular} & $\begin{array}{l}\text { Puna socijalna i } \\
\text { prostorna rezili- } \\
\text { stentnost, koja pruža } \\
\text { mesta za primanje } \\
\text { šokova i stabilizaciju } \\
\text { za razvojni društveni } \\
\text { kapital. }\end{array}$ & Nema granica. & $\begin{array}{l}\text { Urbana bezbednost je } \\
\text { integralni deo socijalne } \\
\text { rezilistentnosti }\end{array}$ \\
\hline
\end{tabular}




\title{
Literatura
}

1. Castells, M. (2000). The Rise of the Network Society. Oxford: Blackwell Publishing.

2. Dovey, K. (1999). Framing Places: Mediating Power in Built Form. New York: Routledge.

3. Faludi, A. (1984). Planning Theory. Oxford: Pergamon press.

4. Hillier, B. (2004). Space is the machine, UCL.

5. Habermas, J. (1984). The Theory of Communicative Action - Volume One: Reason and the Rationalization of Society. Boston: Beacon Press.

6. Healey, P. (1997). Collaborative Planning: Shaping Places in Fragmented Societies. London: Macmillan Press.

7. Holling (2001). Understanding the Complexity of Economic, Ecological, and Social Systems, Ecosystems, Springer-Verlag.

8. Linč, K. (1974). Slika jednog grada. Beograd: Izdavačko preduzeće Građevinska knjiga.

9. Madanipour, A. (1996). Design of Urban Space: An Inquiry into a Socio-spatial Process. Baffins Lane, Chichester: John Wiley \& Sons Ltd.

10. Mrđenović, T. (2010). Patent No. 01 / Integralna igra urbanog dizajna. Srbija, Beograd.

11. Tschumi, B. (1994). Architecture and Disjunction, Boston: MIT Press.

12. UN-Habitat, (2016). New Urban Agenda, https://unhabitat.org/new-urban-agendaadopted-at-habitat-iii/

13. Woolcock Michael, N. D. (1999). Social Capital: Implications for Development Theory, Research and Policy. World Bank Research Observer, 1-49.

\section{CITY AS SECURITY SYSTEM OVER THE HISTORY TILL NOWADAYS: WHAT KIND OF BORDERS DO WE NEED IN URBAN DESIGN?}

\begin{abstract}
Summary
The main purpose of the formation and existence of cities is clearly the provision of security for the city inhabitants at all levels. The city is essentially over the history in fact primarily a security system. Without the existence of the security dimension of the city would lose the purpose of their existence and importance as well as the attractive forces. Safety of the city began with the pursuit and choice inaccessible and hard to reach locations to accommodate any urban system, through the construction of protective fencing - construction claims about the defensive wall around the fortress city, through strictly controlled entry into the city and strictly controlled entry into the city, conditioned by giving status "citizen" or groups of individuals, families, certain layers. Only from the
\end{abstract}


moment when the city begins the expansion of its walls is beginning to introduce the absoluteness of achieving security of the closed security system. Since then, beginning to "establish" model various types of safety systems, that is, the formation of dispersed security model cities that were characterized by the mutually recognized by the concept of the realization of operational safety. In this sense, the goal of this study is to identify the relationships between the impact of the security system on the formation of conceptual development model cities that were created and changed through time as a consequence seen attempt to search for an answer to what kind of security measures and systems (methods, methods and models of security have a crucial impact on the composition and the development of cities of the future. in this context, we can preliminarily identify the following scale model of "security of cities", which are themselves built into special security systems which at the end of the debate, originated in fact from these models. At this point we can observe the following models security of cities:

- controlled cities,

- age-segregated cities,

- institutional security-controlled cities,

- open cities,

- cultural and educational cities,

- market-development concept of security of cities,

- managing security and development towns,

- production-creative concept of the city,

- smart cities,

- computer-based security cities.

City as cultural artefact has a primal role in ensuring safety for its citizens and resources from or for it is built. Either it cherishes the blood routs of our tradition or the products of our civilisation both with the resources that are crucial for human survival and progress. The morphological patterns of city design tell us a story of its concepts of urban safety: from fortification to networking, opening questions on what kind of urban design do we need today in order to integrate different cultures into city and everyday life, and do "self corrections" in order to be resilient to any kind of brutal acts in urban space as well as to ensure quality of place on all its spatial levels from macro- to micro-urban design. The paper discusses safety from the aspect of borders in urban paradigms, especially in urban design, assuming that the integrated urban design can provide an adequate level of openness and closure in order to be resilient to any kind of crime. Therefore, it leans on resilient concept, systemic urban planning and urban design theories, theory of social capital as a productive city force making linkages to its urban form and morphology, taking into account space syntax theory of urban design, image of the city, architecture and disjunction, as well as participative urban design. The aim of the paper is to enlighten the relation between the type of social capital, bordering and city design, resulting in classification and relation between urban design theories, social resilience type of borders and level of urban safety.

Key words: urban design, urban safety, resilience, social resilistence 